\title{
Effects of intramuscular injections of folic acid on serum folates, haematological status and growth performance of growing-finishing pigs
}

\author{
JJ Matte *, CL Girard, R Bilodeau, S Robert \\ Research Station, Agriculture Canada, Lennoxville, Quebec J1M 1Z3, Canada
}

(Received 20 April 1989; accepted 15 November 1989)

\begin{abstract}
Summary - In a first trial, 48 piglets aged 5 weeks, grouped into 6 blocks of 8 pigs each, were used to determine the effect of intramuscular injections of folic acid on serum folates, haematological status, growth performance and carcass characteristics. Each block consisted of 2 pens of 4 pigs; in one pen, pigs received, by weekly intramuscular injections, an increasing volume of a solution containing $5 \mathrm{mg} / \mathrm{ml}$ folic acid, while in the other the animals were non-injected controls. The concentration of serum folates in treated pigs was $19 \%$ higher $(P=0.005)$ than in controls. There was no effect of treatment $(P \geq 0.29)$ on haemoglobin and haematocrit. During the starting period, (5-11 weeks) average daily gain was not influenced by folic acid injections but feed intake and feed conversion were decreased $(P=0.07$ and $P=0.05$ respectively). No effect of folic acid $(P \geq 0.23)$ was noted from 11-23 weeks of age, suggesting that the supplement was suboptimal during the growing-finishing period. In a second trial, 72 piglets aged 9 weeks were assigned to 6 blocks of 12 animals each. The following treatments were randomly distributed in each block according to a $2 \times 3$ factorial design: level of feeding (restricted vs ad libitum) and weekly intramuscular injections of increasing volume of solutions containing either 0,15 or $30 \mathrm{mg} / \mathrm{ml}$ of folic acid. The variables studied were the same as in Trial 1 . Concentrations of serum folates varied quadratically $(P=0.0001)$ with the dose injected, a plateau being attained with injections of $15 \mathrm{mg} / \mathrm{ml}$. There was no effect of treatment $(P=0.043)$ on haemoglobin and haematocrit. During the growing period (9-15 weeks), no effect $(P \geq 0.72)$ of folic acid was noted on growth performance. However, during the finishing period (15-21 weeks), folic acid given at a dose of $30 \mathrm{mg} / \mathrm{ml}$ decreased $(P=0.006)$ feed intake while no effect $(P \geq 0.13)$ of the vitamin supplementation was noted on average daily gain and feed conversion. In both trials, there was no effect $(P \geq 0.21)$ of any treatments on carcass characteristics. These results indicate that a supplement of folic acid administered by intramuscular injections was effective in increasing concentration of serum folates of starting or growing-finishing pigs. This supplement may be associated with a decrease in feed intake.
\end{abstract}

folate / haematological status / growth performance / fattening pig

Résumé - Effet de différents apports d'acide folique sur l'évolution des folates sériques et les performances zootechniques des porcs d'abattage. Dans un premier essai, 48 porcelets âgés de 8 semaines ont été répartis en 6 blocs de 8 animaux chacun afin de déterminer l'effet d'injections intramusculaires d'acide folique sur les folates sériques, le profil hématologique, les performances de croissance et les caractéristiques charcutières. Chaque bloc était constitué de deux en-

\footnotetext{
* Correspondence and reprints
} 
clos de 4 porcs chacun; dans l'un de ces enclos, les porcs ont reçu, par voie intramusculaire, un volume croissant d'une solution, contenant $5 \mathrm{mg} / \mathrm{ml}$ d'acide folique alors que dans l'autre les animaux, servant de groupe témoin, n'ont pas été injectés. Les concentrations de folates sériques ont été de $19 \%$ plus élevées $(\mathrm{P}=0,005)$ ches les porcs traités comparativement aux porcs témoins. Aucun effet du traitement $(\mathrm{P} \geq 0,29)$ n'a été observé sur l'hémoglobine ou l'hématocrite. Le gain de poids moyen quotidien n'a pas été influencé par les injections d'acide folique pendant la période de début (5-11 semaines) mais la prise alimentaire $(P=0,07)$ et le taux de conversion $(P=0,05)$ ont été diminués. Aucun effet de l'acide folique ( $\mathrm{P} \geq 0,23$ ) n'ayant été observé entre l'âge de 11 et 23 semaines, il est possible que le supplément administré pendant la période de croissance et de finition ait été suboptimal. Lors d'un second essai, 72 porcelets âgés de 9 semaines ont été répartis en 6 blocs de 12 animaux chacun. A l'intérieur de chaque bloc, les traitements factoriels $(2 \times 3)$ suivants ont été distribués: niveau d'alimentation (restreint vs libéral) et injections intramusculaires d'un volume croissant d'une solution contenant 0,15 ou $30 \mathrm{mg} / \mathrm{m} /$ d'acide folique. Les variables étudiées ont été les mêmes que dans l'essai précédent. Les concentrations de folates sériques ont varié de façon quadratique $(\mathrm{P}=0,0001)$ avec la dose injectée, un plateau étant atteint à la dose de $15 \mathrm{mg} / \mathrm{ml}$. Aucun effet du traitement $(\mathrm{P} \geq 0,43)$ n'a été observé sur l'hémoglobine ou l'hématocrite. Pendant la période de croissance (9-15 semaines) les performances zootechniques n'ont pas été influencées par le supplément d'acide folique $(\mathrm{P} \geq 0,72)$. Par contre, suite aux injections de $30 \mathrm{mg} / \mathrm{ml}$ d'acide folique en période de finition (15-21 semaines), la prise alimentaire a diminué $(P=0,006)$; aucun effet de l'acide folique $(P \geq 0,13)$ n'a été noté sur le gain de poids moyen quotidien ou le taux de conversion. Dans les deux essais, il n'y a pas eu d'effet $(\mathbf{P}>0,21)$ de traitements sur les caractéristiques charcutières. Un supplément d'acide folique administré par injections intramusculaires augmente donc les concentrations de folates sériques et semble entraîner une réduction de la prise alimentaire.

folate / statut hématologique / performance de croissance / porc d'abattage

\section{INTRODUCTION}

Folic acid has an essential nutritional role in mammals through its involvement in synthesis of DNA, RNA (Herbert and Das, 1976) and proteins (Chang and Kaiser, 1972). Tissues with a high rate of cell turnover such as red blood cells are primarily dependent upon an adequate supply of folic acid (Davis and Nichols, 1988). The fast growth rate of pigs during the first 6 months after birth requires intense cellular hyperplasia and hypertrophy of tissues as well as accretion of protein (Whittemore et al, 1988). In growing-finishing pigs, the folates provided by ingredients of the diet, bacterial synthesis and coproghagy have usually been considered sufficient to meet the animal's requirements (ARC, 1981; INRA, 1984; NRC, 1988), despite the lack of data confirming it. Nevertheless, folates from the diet are likely to be the main relia- ble source of this vitamin since coprophagy, as recently suggested by Bilodeau et al (1989) and de Passillé et al (1989), only seems to play a minor role in the Bcomplex vitamin status of fattening pigs.

Easter et al (1983) reported no change in gain or feed utilization after dietary addition of 0.5 or $1.5 \mathrm{ppm}$ of folic acid during the starting, growing and finishing periods. However, no data on the efficiency of the dietary folate supply by feed analysis and/ or measurement of folate status of the animals were included in that study. Such information is critical considering the lability of folic acid to heat and light (EK and Magnus, 1980; Ford et al, 1983). The stability of the vitamin in premixes or feeds is not well documented (Wornick, 1968) but it is known that pelleting of diets reduces the high levels of folic acid naturally present in lucerne meal (Frape, 1985). Therefore, it seems that supplying additional folic acid 
via intramuscular injections would be a more reliable research tool in order to overcome the potential problems associated with stability of the vitamin. A first experiment was undertaken to measure the changes in folate status as well as production and haematological variables of pigs following intramuscular injections of folic acid during the starting and growingfinishing periods. The results of this first trial suggested that the supplementary folic acid used was suboptimal during the growing-finishing periods. Therefore, a second experiment using higher doses of folic acid than in Trial 1 and measuring similar variables was carried out in order to study particularly the growing and finishing periods.

\section{MATERIALS AND METHODS}

\section{Trial 1}

Forty-eight 5-week-old piglets (Yorkshire $x$ Landrace) weighing approximately $7.8 \mathrm{~kg}(\mathrm{CV}=$ $10.3 \%$ ) were assigned by weight to 6 blocks of 8 pigs each. Piglets were weaned at 4 weeks of age and, after one week of adaptation to the experimental diet, were moved into experimental pens. Each block consisted of 2 pens of 4 pigs ( 2 castrates and 2 females) which were raised throughout the experimental period on a slatted floor. In one of the 2 pens, pigs received weekly intramuscular injections of a solution containing $5 \mathrm{mg} / \mathrm{ml}$ of folic acid ${ }^{1}$. The volume of injection was $1 \mathrm{ml}$ until $20 \mathrm{~kg}$ bodyweight, $2 \mathrm{ml}$ until $45 \mathrm{~kg}$ bodyweight and $3 \mathrm{ml}$ until $90 \mathrm{~kg}$ bodyweight. This increase in injected volumes was designed to simulate the progression of folic acid intake when supplied by the diet. In the other pen, pigs were non-injected controls. It was impossible under the conditions of the present experiment to inject these animals with a placebo. However, this non-injected group was judged as a valid control, since treated pigs were injected only once a week; the stress associated with blood sampling or injections is known to have very short-term effects (maximum of $4 \mathrm{~h}$ ) on haematological and biochemical variables (Dubreuil et al, 1989). Haematological and serum folate measurements as well as growth performances and carcass characteristics from this control group have been previously presented in a study on the effect of floor type on the evolution of some B-vitamins during growth of pigs (Bilodeau et al, 1989).

Feed intake in each pen and individual weight of pigs were measured every fortnight. The animals were fed, ad libitum, diets computed to contain respectively for the starting and growing-finishing period, 3.33 and $3.22 \mathrm{Mcal}$ DE, 19.4 and $16.9 \%$ crude protein, 0.96 and $0.83 \%$ lysine, 1.15 and $0.98 \% \mathrm{Ca}$ and 0.77 and $0.69 \%$ total $P$. There was no addition of folic acid in any of the 2 diets; the calculated and measured levels of folates in the starting diet were 0.62 and $0.47 \mathrm{mg} / \mathrm{kg}$, respectively while the corresponding values were 0.65 and 0.46 $\mathrm{mg} / \mathrm{kg}$ in the growing-finishing diet. Detailed composition is given by Bilodeau et al (1989). Blood samples taken by jugular venipuncture were collected every two weeks immediately before the injection of folic acid. After 18 weeks of experimentation, pigs were slaughtered and the carcasses graded according to the Canadian hog grading system (Anonymous, 1979).

Dietary folates were analysed in duplicate on 3 hydrolysates of the same sample with commercial radioassay kits using [ $\left.{ }^{125} \mid\right] P G A$ as described by Tremblay et al (1986). Preparation of samples before the assay was carried out according to a method adapted from Cerna and Kas (1983). In a conical $50 \mathrm{ml}$ tube, $0.1 \mathrm{~g}$ of feed was mixed with $12 \mathrm{ml}$ of Mcllvain buffer (for $100 \mathrm{ml}: 0.2 \mathrm{M} \mathrm{Na}_{2} \mathrm{HPO}_{4}, 50 \mathrm{mg}$ ascorbic acid, distilled water was added, $\mathrm{pH}$ adjusted to 4.6 with $\mathrm{NaOH} 3.3 \mathrm{M}$ and completed with distilled water up to $100 \mathrm{ml}$ ) and transferred to an autoclave for $10 \mathrm{~min}$ at $121^{\circ} \mathrm{C}$. The $\mathrm{pH}$ was adjusted to 7.0 with $\mathrm{NaOH} 3.3 \mathrm{M}$ and the volume brought to $20 \mathrm{ml}$ with distilled water. The solution was vortexed and then centrifuged at $3000 \mathrm{~g}$ for 10 $\mathrm{min}$. The supernatant was used for folate determination. The effect of chicken pancreas conjugase (transformation of poly- to monoglutamates) on concentrations of folates was tested using the method described by Cerna and Kas

1 Folvite ${ }^{\circledR}$, parenteral solution no 4154, Cyanamid Canada Inc, Montréal, Quebec, Canada 
(1983). No effect of conjugase was noted on concentrations of dietary folates, and subsequently all assays were run without pretreatment with conjugase. The results seem to confirm previous observations (Rothenberg et al, 1974; Schreiber and Waxman, 1974) on the versatility of the radioassay technique for monoand polyglutamates. Results of parallelism tests were satisfactory (CV $=10 \%$ ) between 0 and $5 \mathrm{mg} / \mathrm{kg}$ and inter-assay CV was $9.1 \%$. Recovery tests from a simulated mixing in the laboratory gave a mean of $94.2 \%$.

Data were analysed as a complete random block design using the General Linear Models procedure of SAS (1985). The following model was used: $Y_{i j k}=\mu+B_{i}+F_{j}+B F_{i j}+T_{k}+B T_{i k}+$ $\mathrm{FT}_{\mathrm{jk}}+\mathrm{BFT}_{\mathrm{ijk}}+e_{\mathrm{ijk}}$, where $Y_{\mathrm{ijk}}$ indicates the following dependent variables: serum folates, haemoglobin or haematocrit. The overall mean is $\mu ; B_{i}$ is the effect of block; $F_{i}$ is the effect of folic acid administration and $T_{k}$ is the effect of age. Least square means were compared using orthogonal contrasts when appropriate. Analysis of repeated measurements was made according to the procedure of Gill and Hafs (1971). Average daily gain, feed intake and feed conversion were analysed for each feeding period: weeks 5-11 for the starting period, and weeks 11-23 for the growing-finishing one. Data were submitted to a model similar to that described previously but the independent variable $T_{k}$ was omitted. Carcass characteristics were also analysed using this last model.

\section{Trial 2}

Seventy-two 8-week-old piglets (Yorkshire $x$ Landrace) weighing approximately $19.8 \mathrm{~kg}$ $(C V=12.3 \%)$ were assigned by weight to 6 blocks of 12 pigs each. After 1 week of adaptation to the experimental diet, animals were grouped 2 per pen ( 1 castrate and 1 female) and raised on slatted floors throughout the experimental period. The following treatments were randomly distributed within a block according to a $2 \times 3$ factorial design: level of feeding (restricted vs ad libitum) and weekly intramuscular injections of folic acid $(0,15$ or $30 \mathrm{mg} / \mathrm{ml})$. Pigs in the restricted feeding group were fed twice daily and received between $90-95 \%$ of the intake recorded in the ad libitum group where animals were fed as described in Trial 1. The composition of each diet is presented in table I. In each feeding group, pigs were injected with $1 \mathrm{ml}$ of one of the solutions of folic acid up to $45 \mathrm{~kg}$ of bodyweight, $2 \mathrm{ml}$ up to $65 \mathrm{~kg}$ and $3 \mathrm{ml}$ up to $85 \mathrm{~kg}$. In the control $(0 \mathrm{mg} / \mathrm{ml})$ pen, pigs were injected with a corresponding volume of a saline solution $(\mathrm{NaCl}, 0.9 \%)$. At the end of the experiment, pigs were slaughtered and carcass graded according to the new Canadian hog grading system (Anonymous, 1986). Dressing percentage was also measured.

Feed intake per pen was recorded twice a week and individual weights were taken every fortnight. Blood sampling procedure, haematological and serum folate measurements were performed as in the first trial.

Data were analysed as a complete random block design using the General Linear Models procedure of SAS (1985). The following model was used: $Y_{i j k l}=\mu+B_{i}+A_{i}+F_{k}+A F_{j k}+B A_{i j}+$ $B F_{i k}+B A F_{i j k}+T_{1}+B T_{i l}+A T_{i j}+F T_{k l}+B A T_{i j l}+$ $B F T_{i k l}+B A F T_{i j k l}+\theta_{i j k l}$, where $Y_{i j k l}$ indicates the following dependent variables: serum folates, haemoglobin or haematocrit. The overall mean is $\mu$; $B_{i}$ is the effect of block; $A_{j}$ is the effect of type of feeding; $F_{k}$ is the effect of folic acid administration and $T_{1}$ is the effect of age. Least square means were compared using orthogonal contrasts when appropriate. Analysis of repeated measurements were made according to the method of Gill and Hafs (1971). The concentration of serum folates before the initiation of treatments (9 weeks) was used as a covariate in the analysis of the dependent variable serum folates. Average daily gain, feed intake and feed conversion were analysed for each feeding period: weeks 9-15 for growing period and weeks 15-21 for the finishing one. Data were submitted to a model similar to that described above, the independent variable $T_{1}$ being omitted. Carcass characteristics were also analysed using this last model.

\section{RESULTS}

\section{Trial 1}

The concentration of serum folates (fig 1) in pigs injected with folic acid was approximately $19 \%$ higher $(P=0.005)$ than in those injected with saline. The effect of 
Table I. Composition of the experimental diets (Trial 2). * Provided per $\mathrm{kg}$ of diet a minimum of: $\mathrm{Mn}$, $30 \mathrm{mg} ; \mathrm{Zn}, 100 \mathrm{mg} ; \mathrm{Fe}, 100 \mathrm{mg} ; \mathrm{Cu}, 25 \mathrm{mg}$; I, $300 \mu \mathrm{g}$; vitamin A, 80000 IU; vitamin $\mathrm{D}_{3}, 1500 \mathrm{IU}$; vitamin E, $30 \mathrm{IU}$; menadione, $2.2 \mathrm{mg}$; thiamine, $1 \mathrm{mg}$; riboflavin, $4 \mathrm{mg}$; niacin, $20 \mathrm{mg}$; pantothenic acid, $13 \mathrm{mg}$; folic acid, $500 \mu \mathrm{g}$; pyridoxine, $1.5 \mathrm{mg}$; biotin, $200 \mu \mathrm{g}$; vitamin $\mathrm{B}_{12}, 15 \mu \mathrm{g}$; choline, $300 \mathrm{mg}$.

Ingredients

Diets

Growing

Finishing

Ad libitum

Restricted

Ad libitum

Restricted

\begin{tabular}{|c|c|c|c|c|}
\hline Corn & 595 & 659 & 400 & 580 \\
\hline Barley & 120 & - & 215 & 185 \\
\hline Oat & - & - & 207 & - \\
\hline Soybean meal $(47.5 \%)$ & 230 & 265 & 140 & 175 \\
\hline Animal fat & 10 & 28 & - & 20 \\
\hline Limestone & 15.5 & 16.5 & 12.5 & 13.5 \\
\hline Dical/phosphate & 20 & 21 & 17 & 18 \\
\hline Salt & 5 & 6 & 5 & 5 \\
\hline Mineral premix * & 1.5 & 1.5 & 1.0 & 1.0 \\
\hline Vitamin premix * & 3.0 & 3.0 & 2.5 & 2.5 \\
\hline \multicolumn{5}{|l|}{ Composition } \\
\hline \multicolumn{5}{|l|}{ Energy (Mcal) } \\
\hline calculated (DE) & 3.29 & 3.42 & 3.08 & 3.32 \\
\hline analysis (GE) & 3.87 & 3.97 & 3.90 & 3.82 \\
\hline \multicolumn{5}{|l|}{ Protein $(\%)$} \\
\hline calculated & 17.8 & 18.7 & 15.2 & 15.7 \\
\hline analysis & 18.3 & 18.7 & 16.2 & 17.2 \\
\hline \multicolumn{5}{|l|}{ Lysine $(\mathrm{g} / \mathrm{kg})$} \\
\hline calculated & 9.2 & 10.0 & 7.1 & 7.7 \\
\hline $\begin{array}{l}\mathrm{Ca} \% \\
\text { calculated }\end{array}$ & 1.11 & 1.17 & 0.92 & 0.98 \\
\hline \multicolumn{5}{|l|}{$\mathrm{P}(\%)$} \\
\hline calculated & 0.72 & 0.74 & 0.65 & 0.67 \\
\hline \multicolumn{5}{|l|}{ Folates (mg/kg) } \\
\hline calculated & 1.11 & 1.12 & 1.03 & 1.04 \\
\hline analysis & 1.0 & 1.07 & 0.64 & 0.72 \\
\hline
\end{tabular}

age on concentration of serum folates was variable (age quintic, $P=0.0001$ ). There was a quintic increase with age $(P=0.007)$ of haemoglobin and haematocrit but no effect $(P \geq 0.29$ ) of treatments was noted. Mean haemoglobin and haematocrit values were $11.5 \mathrm{~g} / \mathrm{dl}(\mathrm{CV}=7.3 \%)$ and $39.1 \%$ $(\mathrm{CV}=6.6 \%)$, respectively.
During the starting period (5-11 weeks), injections of folic acid improved $(P=0.05)$ feed conversion (table II). There was no effect of injection ( $P=0.56$ ) on average daily gain, but feed intake tended $(P=0.07)$ to be lower in treated animals. During growing-finishing period (11-23 weeks), there was no effect $(P>0.23)$ of treatment on 


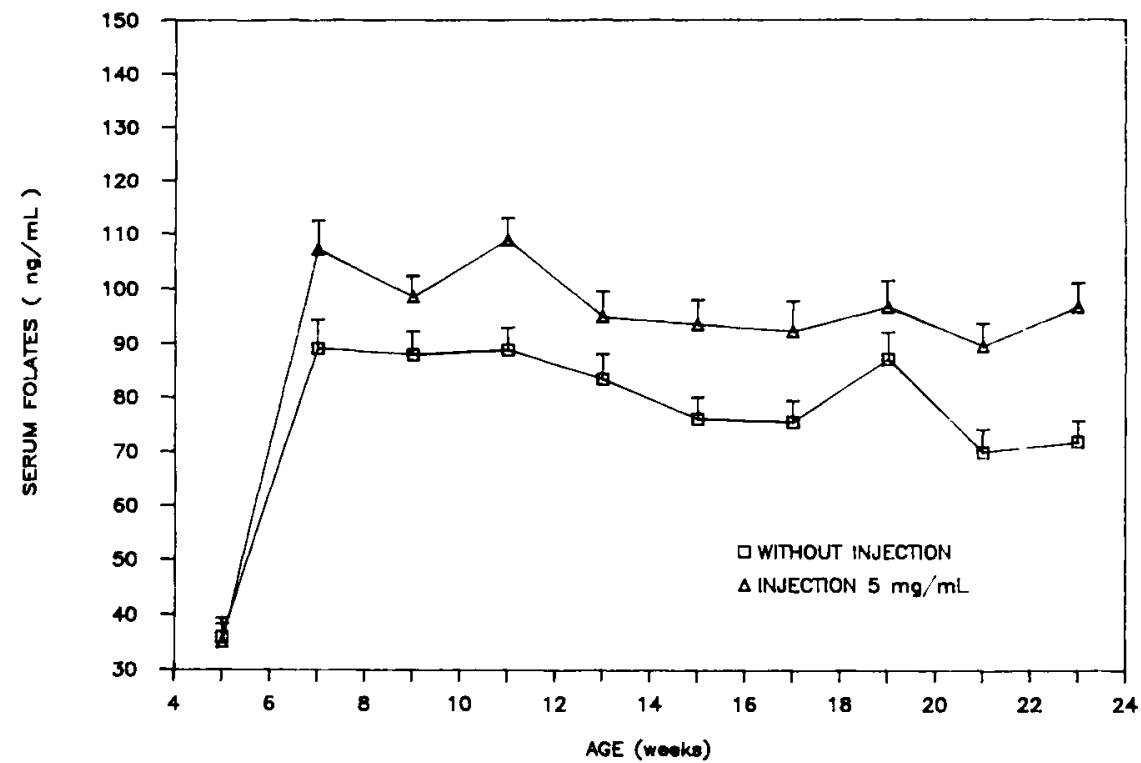

Fig 1. Concentrations (means $\pm S E$ ) of serum folates during starting, growing and finishing periods of pigs injected or not with folic acid (Trial 1).

average daily gain, feed intake or feed conversion. Weight of warm carcasses, backfat thickness (sum of maximum shoulder and loin backfat) and carcass index were similar $(P \geq 0.34)$ between treatments, the mean values being respectively $77.38 \mathrm{~kg}(\mathrm{CV}=8.3 \%), 54.9 \mathrm{~mm}(\mathrm{CV}=$ $31.9 \%)$ and $105.0(\mathrm{CV}=5.0 \%)$.

\section{Trial 2}

The concentration of serum folates (fig 2) increased in pigs injected with folic acid (quadratic effect of dose; $P=0.0001$ ) as compared to those injected with saline, a plateau being attained with injections of 15 and $30 \mathrm{mg} / \mathrm{ml}$. The effect of age on con-

Table II. Average daily gain (ADG), feed intake (I) and feed conversion (I/ADG) of pigs injected or not with folic acid (Trial 1).

\begin{tabular}{lcccccc}
\hline \multicolumn{1}{c}{ Treatment } & \multicolumn{7}{c}{ Age (weeks) } \\
& & $5-11$ (Starting) & & \multicolumn{2}{c}{ 11-23 (Growing-finishing) } \\
& ADG & 1 & I/ADG & ADG & 1 & I/ADG \\
\hline & & & & & & \\
Without injection & 0.47 & 0.96 & 2.07 & 0.78 & 2.45 & 3.15 \\
Injection (5 mg/ml) & 0.46 & 0.91 & 1.99 & 0.78 & 2.39 & 3.05 \\
& & & & & & \\
Probabilities & 0.56 & 0.07 & 0.05 & 0.83 & 0.37 & 0.23 \\
CV & 5.51 & 4.38 & 2.43 & 5.40 & 3.88 & 4.02 \\
\hline
\end{tabular}


centration of serum folates was significantly different between types of feeding (feeding $x$ age cubic; $P=0.0002$ ); the overall difference between ad libitum and restricted feeding, however, was small with values of $105.0 \mathrm{ng} / \mathrm{ml}(\mathrm{CV}=34.6 \%)$ vs 99.7 $\mathrm{ng} / \mathrm{ml}(\mathrm{CV}=32.9 \%)$, respectively. There was a linear increase with age $(P=0.0001)$ of haemoglobin and haematocrit but no effect of treatments $(P \geq 0.43)$. Mean haemoglobin and haematocrit values were $12.9 \mathrm{~g} / \mathrm{d}](\mathrm{CV}=5.4 \%)$ and $39.5 \%$ (CV $=5.0 \%)$, respectively.

Feed conversion was lower in restricted than in ad libitum feeding during both the growing $(P=0.05)$ and finishing $(P=$ 0.0001 ) periods (table III). During the growing period (9-15 weeks), no effect of folic acid $(P \geq 0.72)$ was noted on growth performances. However, the injection of a solution of $30 \mathrm{mg} / \mathrm{ml}$ folic acid decreased (injection linear; $P=0.006$ ) feed intake during the finishing period (15-21 weeks); a $5 \%$ decrease was observed in the ad libitum group between 0 and $30 \mathrm{mg} / \mathrm{ml}$ (feeding injection linear; $P=0.03$ ). Some changes were also noted in weight gain and feed conversion but the differences between levels of injected folic acid were not significant $(P=0.13$ and $P=0.20$, respectively). Weight of warm carcasses, lean and dressing percentage as well as index were similar $(P \geq 0.21)$ between treatments, the mean values being respectively $71.0 \mathrm{~kg}$ $(\mathrm{CV}=6.3 \%), 50.4 \%(\mathrm{CV}=2.0 \%), 81.7 \%$ $(\mathrm{CV}=2.3 \%)$ and $102.0(\mathrm{CV}=5.71 \%)$.

\section{DISCUSSION}

\section{Serum folates}

In humans, the concentration of serum folates is not considered as a reliable indicator of folate status because of its depen-

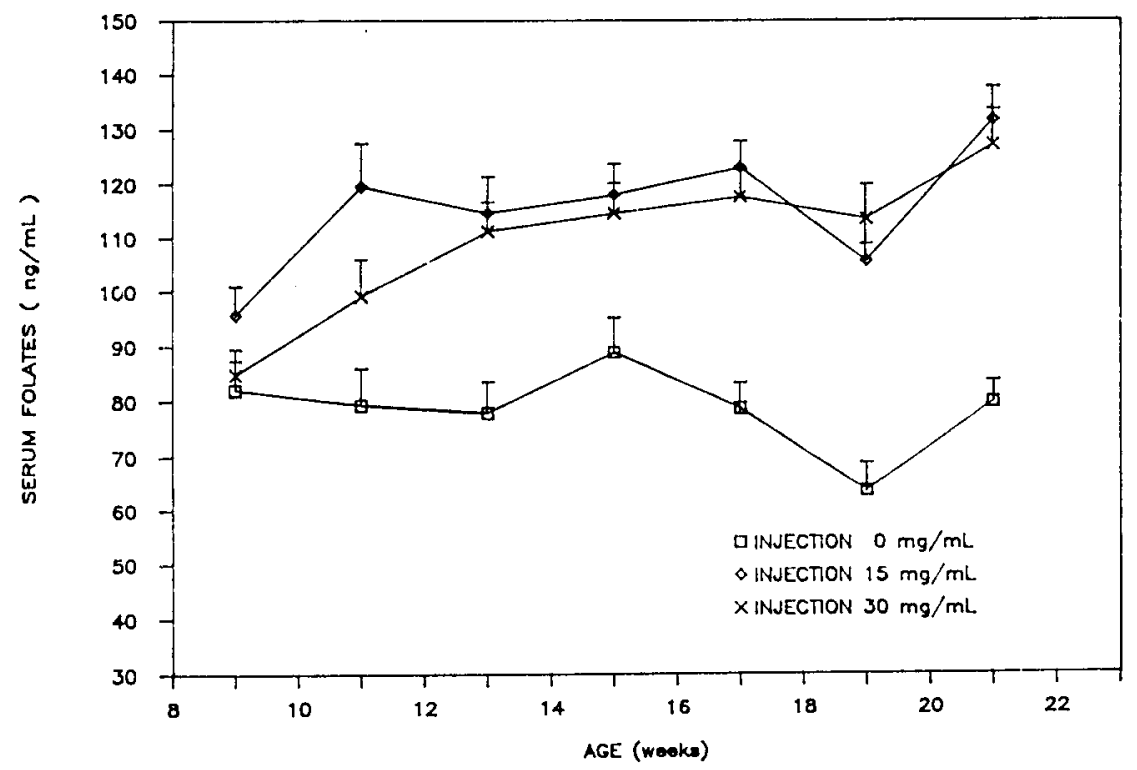

Fig 2. Concentrations (means $\pm S E$ ) of serum folates during the growing and finishing periods of pigs treated or not with folic acid (Trial 2). 
Table III. Average daily gain (ADG), feed intake (I) and feed conversion (//ADG) of pigs according to level of feeding and folic acid treatments (Trial 2). ${ }^{1}$ Injection linear, $P=0.006{ }^{2}$ Feeding * injection linear, $P=0.03$.

\begin{tabular}{|c|c|c|c|c|c|c|c|}
\hline \multirow[t]{2}{*}{$\begin{array}{l}\text { Feeding } \\
\text { regimen }\end{array}$} & \multirow[t]{2}{*}{$\begin{array}{l}\text { Injection of } \\
\text { folic acid }\end{array}$} & \multicolumn{6}{|c|}{ Age (weeks) } \\
\hline & & $A D G$ & I & I/ADG & $A D G$ & 1 & $I / A D G$ \\
\hline \multicolumn{8}{|l|}{ Ad libitum } \\
\hline & saline & 0.73 & 1.58 & 2.17 & 0.76 & 2.45 & 3.24 \\
\hline & $15 \mathrm{mg} / \mathrm{ml}$ & 0.73 & 1.60 & 2.19 & 0.71 & 2.48 & 3.49 \\
\hline & $30 \mathrm{mg} / \mathrm{ml}$ & 0.74 & 1.59 & 2.14 & 0.71 & 2.33 & 3.29 \\
\hline \multicolumn{8}{|l|}{ Restricted } \\
\hline & saline & 0.69 & 1.42 & 2.05 & 0.75 & 2.26 & 3.03 \\
\hline & $15 \mathrm{mg} / \mathrm{ml}$ & 0.69 & 1.40 & 2.02 & 0.73 & 2.21 & 2.97 \\
\hline & $30 \mathrm{mg} / \mathrm{ml}$ & 0.70 & 1.40 & 2.01 & 0.75 & 2.22 & 2.97 \\
\hline \multicolumn{8}{|c|}{ Probabilities } \\
\hline Feedi & & 0.09 & 0.0001 & 0.05 & 0.23 & 0.0001 & 0.0001 \\
\hline Inject & & 0.72 & 0.99 & 0.74 & 0.13 & $0.01^{1}$ & 0.20 \\
\hline Feedi & $g$ *Injection & 0.97 & 0.76 & 0.86 & 0.39 & $0.04^{2}$ & 0.49 \\
\hline CV & & 4.8 & 3.9 & 5.3 & 5.2 & 2.8 & 5.9 \\
\hline
\end{tabular}

dency upon short-term dietary changes (Rothenberg et al, 1974; Sauberlich, 1975). However, as noted previously by Matte et al (1984) with gestating sows, circulating serum folates in swine are likely to properly reflect the status in folates because of the uniformity of the feeding regimen within a herd. Moreover, in order to avoid any immediate interference due to feeding, blood samples were taken, in the present experiment, at the same time of the day (0830 to 1000) after a fasting period of at least $12 \mathrm{~h}$.

Serum folates increased by over $100 \%$ in pigs from 5-7 weeks of age. This increase is most likely due to the difference in amount and type of feed consumed during this period (dry feed) compared to before weaning (milk). Indeed, it is known that the concentration of folates in sow's milk (Matte and Girard, 1989) represents, on a dry matter basis, about 10 times less folates than in cereal-based diets. In both trials, the concentration of serum folates in control animals varied between 70-90 ng/ $\mathrm{ml}$, from 9 weeks of age to the end of the finishing period. These fluctuations as well as the interaction feeding $x$ age cubic (Trial 2) might be associated with variations in availability of folic acid between the different diets; the type of ingredients varied between feeding treatments and between periods. Considering the control groups in both trials, it appears that the higher levels of folates provided by diets in Trial 2 as compared to Trial 1 has a limited impact on the evolution of the concentration of folates as compared to weekly intramuscular injections during the growing-finishing period. Animals injected with folic acid had ap- 
proximately $19 \%$ more circulating serum folates than control animals in Trial 1 and over $40 \%$ in Trial 2 . It therefore seems that the injection of a solution of $5 \mathrm{mg} / \mathrm{ml}$ folic acid (Trial 1) was not sufficient to maximize the concentration of folates in serum. However, the quadratic effect of injection $(P=$ 0.0001 ) in Trial 2 indicated that a plateau in concentration of serum folates was attained after the injection of a solution of 15 $\mathrm{mg} / \mathrm{ml}$ folic acid. Such a plateau might be explained by the presence of serum folatebinding proteins. In humans, serum folates are either free or protein-bound (Markkanen et al, 1972; Wagner, 1985; Zamorano et al, 1985). In pigs, Mantzos et al (1974) noted the presence of a great quantity of unsaturated "avid specific binders" of folic acid in blood plasma of animals between 2 days and 3 years of age. The capacity of these "specific binders" to link folates in serum is not known, but the plateau in concentrations of serum folates suggests that injections of 15 and $30 \mathrm{mg} / \mathrm{ml}$ saturated the folate-binding capacity.

\section{Haematological measurements}

The increase in the serum concentration of folates induced by intramuscular injections of folic acid in both trials had no effect on the evolution of blood haematocrit and haemoglobin. It is known that prolonged folate deficiency may result in haematological disorders of pigs and poor performance (NRC, 1988). It appears that, in both trials, the lower concentrations of folates in control as compared to treated pigs were not indicative of any deficiency associated with haematocrit and haemoglobin.

\section{Growth performance}

In both trials, for some periods, feed intake decreased or tended to be reduced after folic acid treatments. The effect of a supplement of folic acid on feed conversion during the starting period in Trial 1 was mediated by an alteration in feed intake. This effect did not persist during the growing-finishing period in spite of similar differences, in absolute values, between treatments (table II). These results may be due to the fact that the total amount of folic acid given through both the diet and intramuscular injections was, on an ADG basis, higher, $3.0 \mathrm{mg} / \mathrm{kg} \mathrm{ADG}$, during the starting period as compared to a value of $2.6 \mathrm{mg} /$ $\mathrm{kg}$ ADG during the growing-finishing period. It was concluded, therefore, that the supplement of folic acid might be suboptimal during the growing-finishing period. In Trial 2, during the growing period, the ratio was elevated to values of 4.7 and $7.1 \mathrm{mg} /$ $\mathrm{kg} \mathrm{ADG}$ in pigs injected with 15 and 30 $\mathrm{mg} / \mathrm{ml}$, respectively while the corresponding values were 6.2 and 10.0 during the finishing period. It seems that, in order to produce an effect on feed intake, a much higher quantity of folic acid is needed during the finishing period (Trial 2) than during the starting period (Trial 1).

The present results on appetite are similar to previous observations where feed intake tends to be reduced after addition of folic acid to a starting (Lindemann and Kornegay, 1986) and a growing-finishing diet (Easter et al, 1983). One could explain this effect by metabolism of folic acid in brain areas responsible for the control of feed intake. It is known that folates act as cofactors in the synthesis and catabolism of serotonin, norepinephrine and epinephrine (Laborit, 1970). Folic acid can also competitively inhibit the brain L-glutamate decarboxylase, an enzyme essential for the synthesis of gamma-aminobutyric acid (GABA) (Tunnicliff and Ngo, 1977), which is a neurotransmitter involved in the control of feed intake in rat (Grandison and Guidotti, 1977; Kelly and Grossman, 1979; Kelly et al, 1979) and sheep (Girard et al, 
1985). Moreover, a recent study demonstrated that folic acid reverses the action of GABA by acting on the GABA a IIreceptor in the brain (van Rijn et al, 1988).

The entry of folates in cerebrospinal fluid, and probably in the brain, is regulated by a saturable transport system. However, at high concentrations of folates, the transport system is saturated and folates enter the cerebrospinal fluid by diffusion (Spector and Lorenzo, 1975; Ordonez, 1977). Variations in the capacity of saturation of this transport system might explain the inconsistency of folic acid effect on feed intake between Trials 1 and 2. Moreover, assuming that folic acid affects feed intake via brain neurotransmitters, the responses observed in the present experiments would be in agreement with those reported by Hunter et al (1971) and Ch'ien et al (1975) showing wide individual variations in the physiological responses of brain to a supplement of folic acid. Therefore, it is possible that the tendency of feed intake to be reduced following intramuscular injections of folic acid administered during the starting, growing or finishing period was related to an effect of folic acid on the brain neurotransmitters involved in the control of feed intake.

In conclusion, the present results indicate that supplement of folic acid administered by intramuscular injections increased the serum concentrations of folates of starting, growing and finishing pigs but did not affect haematological status. The possible effect of folic acid on feed intake merits further evaluation.

\section{ACKNOWLEDGMENTS}

The authors would like to acknowledge the assistance of M Guillette, M St-Louis, C Plante, J Lévesque, $M$ Morissette, $M$ Vanier, $R$ Lanctôt, $Y$ Dubois and $M$ Daoust for technical support, $M$ Dumas for statistical analysis and $L$ Boisvert for manuscript preparation. This research was subsidized in part by $\mathrm{F}$ Hoffmann-La Roche Ltd, Basle, Switzerland and Mississauga, Canada.

\section{REFERENCES}

Anonymous (1979) Canadian agricultural products standards acts. Hog carcass grading regulations. SOR/79-119. Can Gazette 113 (ii), 486-487

Anonymous (1986) Hog carcass grading regulations, 1986. Can Gazette 120 (ii), 1657-1667

ARC (1981) The Nutrient Requirements of Pigs. Commonwealth Agricultural Bureaux, Slough, UK

Bilodeau R, Matte JJ, De Passillé AM, Girard CL, Brisson GJ (1989) Effects of floor type on serum folates, vitamin $B_{12}$ and biotin and on growth performances of pigs. Can J Anim SCl 69, 779-788

Cerna J, Kas J (1983) New conception of folacin assay in starch or glycogen containing food samples. Nahrung 27, 957-964

Chang YO, Kaiser II (1972) Free and membrane bound ribosomes in experimental animals during $\mathrm{B}_{12}$ and folic acid deficiency. Int $\mathrm{J}$ Vet Nutr Res 42, 482-486

Ch'ien TL, Krumdieck CL, Scott CW Jr, Butterworth CE Jr (1975) Harmful effect of megadoses of vitamins: electroencephalogram abnormalities and seizures induced by intravenous folates in drug-treated epileptics. Am J Clin Nutr 28, 51-58

Davis RE, Nicol DJ (1988) Folic acid. Int J Biochem 20, 133-139

De Passillé AMB, Bilodeau RR, Girard $C L$, Matte JJ (1989) A study on the occurrence of coprophagy behaviour and its relationship to B-vitamin status of growing-finishing pigs. Can J Anim Sci69, 299-306

Dubreuil $P$, Farmer $C$, Couture $Y$, Brazeau $P$, Petitclerc D (1989) Hematological and biochemical changes following an acute stress in control and somatostatin-immunized pigs. Proc Can Soc Anim Sci 39th Annual Conference, July $9-13,32$

Easter RA, Anderson PA, Michel EJ, Corley JR (1983) Response of gestating gilts and starter, grower and finisher swine to biotin, pyri- 
doxine, folacin and thiamine additions to corn-soybean meal diets. Nutr Rep int 28 , 945-954

Ek J, Magnus E (1980) Plasma and red cell folacin in cow's milk-fed infants and children during the first two years of life: the significance of boiling pasteurized cow's milk. Am J Clin Nutr 33, 1220-1224

Ford JE, Hurrel RF, Finot PA (1983) Storage of milk powders under adverse conditions. II. Influence of the content of water-soluble vitamins. Br J Nutr 49, 355-364

Frape DL (1985) Factors affecting the need of supplementary vitamins in pigs. In: Recent Development in Pig Nutrition (Cole DJA, Haresign W, eds) Butterworths, London, 139154

Fuller NJ, Evans PH, Howlet M, Bates CJ (1988) The effects of dietary folate and zinc on the outcome of pregnancy and early growth in rats. Br J Nutr 59, 25t-259

Gill JL, Hafs HD (1971) Analysis of repeated measurements of animals. J Anim Sci 33, 331-336

Girard CL, Seoane JR, Matte JJ (1985) Studies of the role of GABA in the hypothalamic control of feed intake in sheep. Can J Physiol Pharmacol 63, 1297-1301

Grandison L, Guidotti A (1977) Stimulation of food intake by muscimol and beta-endorphin. Neuropharmacology 16, 533-536

Herbert V, Das NC (1976) The role of vitamin $B_{12}$ and folic acid in hemato- and other cellpoiesis. Vitamin Horm 34, 1-30

Hunter R, Barnes J, Curzon G, Kautamaneni BD, Duncan C (1971) Effect of folic acid by mouth on cerebrospinal fluid homovanilic acid and 5-hydroxyindolacetic acid concentration. J Neurol Neurosurg Psychiatry 34, 571-575

INRA (1984) Alimentation des Animaux Monogastriques: Porcs, Lapins, Volailles. Institut National de la Recherche Agronomique, Paris, France

Kelly J, Grossman SP (1979) GABA and hypothalamic feeding systems. II. A comparison of GABA, glycine and acetyl-choline agonists and their antagonists. Pharmacol Biochem Behav 11, 647-652

Kelly J, Rothstein J, Grossman SP (1979) GABA and hypothalamic feeding systems. I.
Topographic analysis of the effects of microinjections of muscimol. Physiol Behav 23, 1123-1124

Laborit H (1970) Sur le rôle possible de l'acide folique dans la physiologie et la physiopathologie du système nerveux central. Agressologie 11, 9-14

Lindemann MD, Kornegay ET (1986) Effect of folic additions to weanling pig diets. In: Va Tech Livestock Res Rep, 1985-86 (Kornegay ET, Gerken J, Knight J, Notter D, eds) 20-22

Mantzos JD, Alevizow-Terzaki D, Gyftaki E (1974) Folate binding in animal plasma. Acta Haematol 51, 204-210

Markkanen TP, Pajula RL, Virtanen S, Himanen $P$ (1972) New carrier protein(s) of folic acid in human serum. Acta Haematol 48, 145-150

Matte JJ, Girard CL, Brisson GJ (1984) Serum folates during the reproductive cycle of sows. J Anim Sci 59, 158-163

Matte JJ, Girard CL (1989) Effects of intramuscular injections of folic acid during lactation on folates in serum and milk and performances of sows and piglets. J Anim Sci 67, 426-431

NRC (1988) Nutrient Requirements of Swine. National Academy Press, Washington, DC, USA, 9th edn

Ordonez LA (1977) Control of the availability to the brain of folic acid, vitamin $B_{12}$, and choline. In: Nutrition and the Brain Vol 1 (Wurtman RJ, Wurtman JJ, eds) Raven Press, New York

Rothenberg SP, daCosta M, Lawson J, Rosenberg $Z$ (1974) The determination of erythrocytes folate concentration using a two-phase ligand-binding radioassay. Blood 43, 437-443

SAS (1985) SAS User's Guide. Statistics. SAS Inst Inc cary, NC

Sauberlich HE (1975) Detection of folic acid deficiency in populations. In: National Research Council. Folic Acid. Biochemistry and Physiology in Relation to the Human Nutrition Requirements. Natl Acad Sci, Washington, DC, 213-232

Schreiber C, Waxman S (1974) Measurements of red cell folate levels by $3 \mathrm{H}$-pteroylglutamic acid (3H-Pte-Glu) radioassay. $\mathrm{Br} J \mathrm{Haematol}$ $27,551-558$

Spector R, Lorenzo AV (1975) Folate transport in the central nervous system. Am J Physiol 229, 777-782 
Tunnicliff G, Ngo TT (1977) Folic acid and the inhibition of brain L-glutamic decarboxylase. Experientia 33, 67-68

Tremblay GF, Matte JJ, Lemieux L, Brisson GJ (1986) Serum folates in gestating swine after folic acid addition to diet. J Anim Sci 63 , 1173-1178

van Rijn CM, van der Velden TJSM, Rodrigues de Miranda JF, Feenstra MGP, Hommes OR (1988) The influence of folic acid on the picrotoxin-sensitive site of $\mathrm{GABA}_{\mathrm{a}}$-receptor complex. Epilepsy Res 2, 215-218
Wagner C (1985) Folate binding proteins. Nutr Rev 43, 293-300

Whittemore CT, Tullis JB, Emmans GC (1988) Protein growth in pigs. Anim Prod 46, 437445

Wornick RC (1968) The stability of microingredients in animal feed products. Feedstuffs 40, 25-31

Zamorano AF, Arnalich F, Sanchez-Casas E, Sicilia $A$, Solis $C$, Vasquez JJ, Gasalla $R$ (1985) Levels of iron, vitamin $B_{12}$, folic acid and their binding protein during pregnancy. Acta Haematol 74, 92-97 